\title{
Proline-Rich Nuclear Receptor Coactivator
} 1

National Cancer Institute

\section{Source}

National Cancer Institute. Proline-Rich Nuclear Receptor Coactivator 1. NCI Thesaurus. Code $C 96356$.

Proline-rich nuclear receptor coactivator 1 (327 aa, $35 \mathrm{kDa}$ ) is encoded by the human PNRC1 gene. This protein plays a role in the coactivation of transcription. 